\title{
The Williams Airway Intubator
}

\author{
Derek Dillane, MB BCh, BAO MMedSci, FCARCSI (1)
}

Received: 19 January 2018/Revised: 13 February 2018/Accepted: 15 February 2018/Published online: 12 March 2018

(C) Canadian Anesthesiologists' Society 2018

The Williams Airway Intubator (often colloquially called the Tudor Williams Airway) is an oral airway devised by Robert Tudor Williams (1928-2017). Born in Swansea, Wales, Williams attended medical school and undertook the greater part of his anesthesia training in Cardiff. He emigrated to Canada in 1960, where he completed the final two years of anesthesia residency in Edmonton, Alberta. He moved to Calgary in 1966 and was one of the founding members of the Department of Anesthesia at the Calgary Foothills Hospital. ${ }^{\mathrm{A}}$

The Williams Airway Intubator, first described in 1981, was designed as an aid for blind oral endotracheal intubation or as a stand-alone oropharyngeal airway ${ }^{1}$ (Figure). During an era pre-dating video laryngoscopy and the widespread availability of affordable flexible bronchoscopy (FB), the device was useful when direct laryngoscopy failed. In correspondence to the British Medical Journal, Dr. Williams reported an $85 \%$ first attempt success rate for tracheal intubation in 500 patients performed by medical and non-medical personnel. ${ }^{2}$

Prior to commercial production, the Williams Airway Intubator was originally constructed by modifying a Portex Guedel airway (Smiths Medical, Hythe, UK) such that the distal half was open on its lingual surface, and the proximal

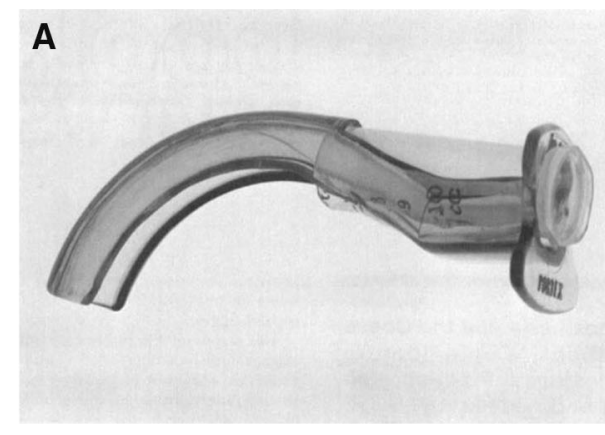

Figure A) The original prototype Williams Airway Intubator was a modified Portex Guedel airway with the distal half open on its lingual surface. The proximal bite area was made circular in cross section by using the barrel of a 10-mL syringe. The image is from Williams $R T$,

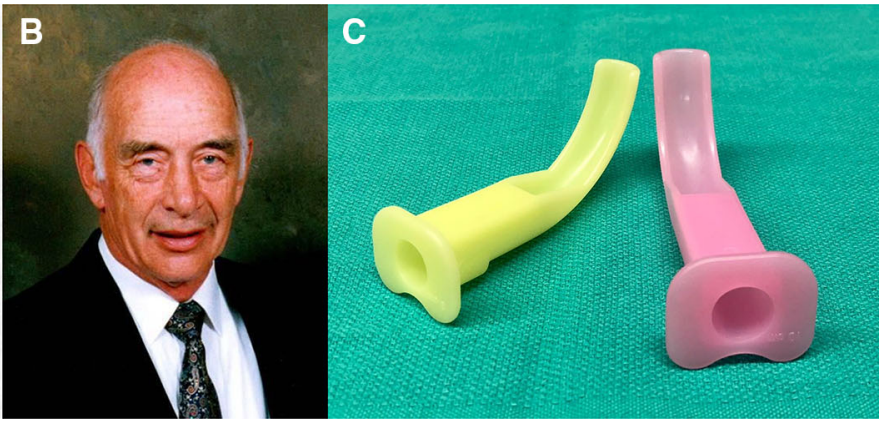

Maltby JR. Airway intubator. Anesth Analg 1982; 61: 309, used with permission. ${ }^{3}$ B) Dr. Robert Tudor Williams: August 20, 1928 - April 22, 2017. C) The Williams Airway Intubator comes in two adult sizes and allows passage of an endotracheal tube up to $8.5 \mathrm{~mm}$ in size
D. Dillane, MB BCh, BAO MMedSci, FCARCSI $(\bowtie)$

Department of Anesthesiology \& Pain Medicine, University of Alberta, Edmonton, AB, Canada

e-mail: dillane@ualberta.ca

\footnotetext{
$\overline{\mathrm{A}}$ The Calgary Herald. Robert Tudor Williams. Obituary. Available from URL: http://www.legacy.com/obituaries/calgaryherald/obituary. aspx?pid=185290667 (accessed February 2018).
} 
half was in the shape of a cylindrical tunnel. ${ }^{1}$ The tubular proximal half served to immobilize the endotracheal tube in the midline, and the open distal segment controlled its trajectory with an element of maneuverability.

Although not primarily intended as a guide for FB, the current Williams Airway Intubator (Mainline Medical Inc., Norcross, GA, USA) has had a second lease on life in this role fulfilling many criteria of the ideal intubating airway. Lamenting the lack of widespread availability of FB in 1981, Dr. Williams described his intubating airway as an alternative, simple, low-cost intubation adjunct. ${ }^{1}$ Its enduring popularity almost four decades later is a testament to its functionality.
Conflicts of interest None declared.

Editorial responsibility This submission was handled by Dr. Hilary P. Grocott, Editor-in-Chief, Canadian Journal of Anesthesia.

\section{References}

1. Williams RT, Harrison RE. Prone tracheal intubation simplified using an airway intubator. Can Anaesth Soc J 1981; 28: 288-9.

2. Williams RT, Strunin L. The oesophageal obturator airway. Br Med J (Clin Res Ed) 1981; 283: 499.

3. Williams RT, Maltby JR. Airway intubator. Anesth Analg 1982; 61: 309 . 